\title{
OPINIÃO
}

\section{Sociedade Rent-Seeking}

Luciano Nakabashi*

Recentemente terminei de lecionar um curso sobre teorias de crescimento econômico para os alunos da Pós-Graduação em Desenvolvimento Econômico da UFPR. Entre vários artigos, apresentei um seminal sobre a Sociedade Rent-Seeking de autoria da professora Anne Kruger, da Universidade Johns Hopkins.

O artigo foi publicado em 1974 e nele se desenvolve uma análise sobre as ineficiências causadas pela intervenção governamental em alguns mercados devido à geração de rendas extraordinárias. O foco da análise foi o setor importador e como a imposição de cotas, ao elevar o preço dos produtos importados, gera uma renda extra para os agentes que operam nesse mercado. Com a elevação dos ganhos, ocorre uma competição para a obtenção de licenças para importação de forma a empregar trabalho e capital de forma não produtiva.

Esse tema é muito atual no Brasil e, certamente, tem efeitos relevantes no PIB. Muitas pessoas e capital estão sendo empregados para a obtenção de rendas geradas por intervenção governamental sem aumentar o PIB. Um exemplo são os elevados salários de alguns funcionários públicos onde as atividades não demandam pessoas com grande nível de qualificação. Em nosso meio, é comum verificar que alguns dos melhores alunos dos programas brasileiros de pós-graduação acabam indo para instituições como o IPEA, Banco Central, Ministérios, Secretarias, Agências Reguladoras etc.

É claro que os candidatos estão respondendo aos incentivos, como salários elevados, estabilidade no emprego, aposentadoria etc. Os atrativos são consideráveis, o que eleva muita a competição na entrada. Assim, os candidatos exitosos possuem boa qualificação inclusive com diplomas de mestrado e doutorado, em muitos casos. No entanto, muitas vezes, eles são alocados em atividades que não demandam muita qualificação. Ou seja, não empregam, em suas atividades diárias, o conhecimento e habilidades adquiridos anteriormente.

Portanto, em muitos casos, todo o esforço realizado anteriormente acaba sendo apenas para ter sucesso no concurso público e não para a execução das atividades que serão praticadas. Essa competição na entrada acaba sendo um desperdício de recursos (tempo se preparando,

\footnotetext{
* Doutor em Economia pela Universidade Federal de Minas Gerais. É professor do Departamento de Economia da Universidade Federal do Paraná e pesquisador do CNPq. Endereço eletrônico: luciano.nakabashi@gmail.com.
} 
realização de cursos de mestrado e doutorado etc.).

É claro que essas instituições demandam pessoas com elevado nível de qualificação, mas apenas em áreas específicas. Para reduzir essa ineficiência, o Governo Federal deveria abrir concursos específicos em áreas que demandam pessoal com elevado nível de qualificação, inclusive com a exigência de diplomas de mestrado e doutorado, pagando o diferencial de salário pela qualificação apenas nessas atividades. Adicionalmente, geraria um efeito colateral positivo ao melhorar as contas públicas.

Este é apenas um exemplo que serve para ilustrar como uma intervenção governamental pode gerar alocação de recursos em atividades não produtivas. Existem inúmeros casos no Brasil que merecem estudos detalhados para a mensuração desses custos. Podemos pensar nas licenças para taxistas, na intervenção governamental no mercado produtivo favorecendo algumas empresas específicas, processos licitatórios, atividades que restringem a entrada de novos produtores etc.

Por um lado, o Governo tem um papel fundamental em muitos setores e no bom funcionamento da economia como um todo. Por outro, é preciso levar em consideração esses custos quando ele interfere no funcionamento do mercado. As intervenções devem ser realizadas de forma a tentar estimular os setores produtivos e reduzir as rendas extraordinárias que geram competição e a consequente alocação de recursos em atividades não produtivas. Infelizmente, esse não é nosso histórico. 